Mozhgan Hayati

Assistant Professor, Payame Noor University, Tehran, Iran

mozhgan.hayat@pnu.ac.ir

Afsaneh Parto

MA School Counseling, Department of Educational Science, Payame Noor University, Qazvin, Iran

AfsanhParto@gmail.com

Editor Científico: José Edson Lara

Organização Comitê Científico

Double Blind Review pelo SEER/OJS

Recebido em 19.03.2018

Aprovado em 22.05.2018 


\title{
The Impact of meta-cognition instruction on perfectionism and the life quality of high school students
}

\begin{abstract}
This study aimed to find out the impact of meta-cognition teaching on perfectionism and the quality of high school students' lives. The study used quasi-experimental method, pre-test, and post-test with a control group. The population of the study included all the high school students in Larestan city during 1396-1397 (2017-2018) academic year. Using convenient sampling method, 30 students were chosen from among the population available, then this sample was divided into two groups of 15 with one being an experimental and the other being the control group. Hill's Perfectionism Questionnaire and Life Quality Questionnaire (SF-36) and singlevariable co-variance data analysis and SPSS version 22 were used in the study in order to analyze the data. The results of the study indicated a significant difference between the experimental and control group in terms of the scores obtained from Perfectionism $(P<0.0001, F=44.20)$ and Life Quality $(P<0.0001, F=30.70)$. It can be concluded that meta-cognition therapy can be effective in lowering the degree of perfectionism and raising the quality of high school students` lives.
\end{abstract}

Key words: Meta-cognition, Perfectionism, Quality of Life, Students

\section{O Impacto da instrução de meta-cognição sobre o perfeccionismo e a qualidade da vida dos estudantes do ensino médio}

\section{Resumo}

Este estudo teve como objetivo descobrir o impacto do ensino de meta-cognição sobre o perfeccionismo e a qualidade da vida dos alunos do ensino médio. $O$ estudo utilizou método quase experimental, pré-teste e pós-teste com um grupo de controle. A população do estudo incluiu todos os alunos do ensino médio na cidade de Larestan durante o ano lectivo 1396-1397 (2017-2018). Usando um método de amostragem conveniente, 30 alunos foram escolhidos entre a população disponível, então esta amostra foi dividida em dois grupos de 15, sendo um experimental e outro sendo o grupo controle. O Questionário de Perfeccionismo de Hill e o Questionário de Qualidade de Vida (SF-36) e análise de dados de co-variância de variável única e SPSS versão 22 foram utilizados no estudo para analisar os dados. Os resultados do estudo indicaram diferença significativa entre o grupo experimental e de controle em termos dos escores obtidos do Perfeccionismo $(P<0,0001, F=44,20)$ e Qualidade da Vida $(P<0,0001, F=30,70)$. Pode-se concluir que a terapia de meta-cognição pode ser efetiva na redução do grau de perfeccionismo e na elevação da qualidade das vidas dos estudantes do ensino médio. 
Palavras-chave: Meta-cognição, Perfeccionismo, Qualidade de Vida, Estudantes

\section{El impacto de la instrucción de metacognición en el perfeccionismo y la calidad de vida de los estudiantes de secundaria}

\section{Resumen}

Este estudio tuvo como objetivo conocer el impacto de la enseñanza de la metacognición en el perfeccionismo y la calidad de vida de los estudiantes de secundaria. El estudio utilizó un método cuasiexperimental, una prueba previa y una prueba posterior con un grupo de control. La población del estudio incluyó a todos los estudiantes de secundaria en la ciudad de Larestan durante el año académico 13961397 (2017-2018). Utilizando un método de muestreo conveniente, se seleccionaron 30 estudiantes de entre la población disponible, luego esta muestra se dividió en dos grupos de 15, uno experimental y el otro grupo control. El cuestionario de perfeccionismo de Hill y el cuestionario de calidad de vida (SF-36) y el análisis de datos de co-varianza de una variable y SPSS versión 22 se usaron en el estudio para analizar los datos. Los resultados del estudio indicaron una diferencia significativa entre el grupo experimental y control en términos de puntajes obtenidos del perfeccionismo $(P<0.0001, F=44.20)$ y calidad de vida $(P<0.0001, F=30.70)$. Se puede concluir que la terapia de metacognición puede ser efectiva para disminuir el grado de perfeccionismo y elevar la calidad de vida de los estudiantes de secundaria.

Palabras clave: metacognición, perfeccionismo, calidad de vida, estudiantes

\section{Introduction}

Adolescence and youth are a critical stage in identity formation process an awareness of whose characteristics and attention to the factors shaping the youngster's identity structure are considered amongst the introductory and crucial needs of young people. For all of those people who have passed from youth and entered the other stage, this is a tangible and palpable experience. It is clear that the formation of one's identity structure starts from the beginning days of life and even before that. Feeling independent while being in the society at the same time and forming their social relationships, young people live a critical period of their lives; if the beginning of this period is not accompanied by the necessary teaching and the required awareness plus 
rationality, it will be full of harms and dangers which may completely change their lives and bring about bitter experiences (Mashayekh and Heydari, 2014.)

Everyone has a tendency for perfectionism and prosperity. By actualizing their potential abilities, human beings attempt to succeed and reach a higher level than they are currently at. In the beginning, perfectionism was thought of an ineffective attribute in which the need for success indicated itself in the form of high and unrealistic personal criteria which results in a situation with a fear of making mistakes at the center of it (Yavariyan, Haghighi, Ramezanpour, and Radfar, 2017). Basically, there is a tendency for prosperity and perfectionism in people's nature, and this tendency shows itself in the form of a positive feature because it creates energy that brings about progress and success. Great scholars' insistence on creating their works and the efforts they make in this regard springs from their perfectionism; however, perfectionism process does not proceed positively in all people's lives. It can be stated that perfectionism benefits the person till when it concerns the person himself.herself and is aimed at activating all his.her potentialities and skills. When the tendency for perfectionism appears in the form of competing with and defeating others merely to get approval and make them happy, it will be negative and unnatural (Aghamohammadiyan Shaarbaf, Zare' Zadeh Kheibari, Horuf Ghannad, and Hokm Abadi, 2014). Those who are naturally.positively perfectionist consider some criteria for themselves, but instead of reaching their goals or not, what matters most of all to them is to make attempts to obtain their objectives. In contrast, negatively.unnaturally perfectionist people or psychopaths are always worried as to whether they will make mistakes, so they never feel winning. Those who are negatively perfectionist, are not satisfied with themselves and scold themselves all the time even if they work better than the others (Mousavi-Moghaddam et.al. 2016).

Quality of life is one of today's issues in health-care and one of the biggest hygienic objectives in order to increase people' health; in recent years, quality of life has been regarded as one of the most important factors in individuals' lives especially the students`lives (Valiyan, 2015). According to Albert Bandura and Quality of Life theory which is the basis of improving quality of life therapy, controlling awareness, thoughts, feelings, and physical senses are the greatest challenges for psychiatrists. Regarding the emphasis of quality of life theory on life satisfaction and experiencing 
mental health, quality of life refers to the quality of awareness, namely, the degree of positiveness of human beings' inner experiences (e.g., thoughts and feelings).

The question posed by this theory is "Are you basically happy and satisfied with your life?" The definition of quality of life based on inner, mental, and personal experience, mental health research indices in general, and quality of life theory in specific which is obtained from a totally objective approach to quality of life, differs from the way health and its measurement is materialistically defined according to welfare. Meanwhile, inner or mental experience approach never ignores the relation of the objective conditions of life, and these conditions form only a part of happiness equation (Seraji, Nasr Abadi and Amirkhani, 2015).

There are various approaches to improve perfectionism and quality of life of the students including meta-cognition therapy. Meta-cognition is defined as any cognition or cognitive process which plays its own role in measurement, introspection, and controlling cognition. At one time, meta-cognition can be considered as a general aspect of cognition which intervenes with all of cognitive processes. Meta-cognition is a multi-dimensional concept which includes knowledge (beliefs), processes and strategies which assess or control cognition (Gorzelsky, G., Driscoll, D. L., Paszek, J., Jones, E., \& Hayes, C, 2016).

The majority of cognitive activities rely on meta-cognitive factors. Moreover, information gathered from metacognitive inspection is often experienced as mental senses which can affect the behavior. Most of the theoreticians distinguish between meta-cognitive knowledge and meta-cognitive regulation. Meta-cognitive knowledge comprises knowledge which people have about their own knowledge.cognition and factors related to influential activities and strategies which bear on their cognition (Trauelsen, A. M., Gumley, A., Jansen, J. E., Pedersen, M. B., Nielsen, H. G. 2016).

In their study titled "A comparison of the efficacy of meta-cognition therapeutical group and group learning of life skills on depression, quality of life, rumination response style, and divorced women`s meta-cognition" Razavi Zade Tabakan and Share (2015) concluded that meta-cognitive therapeutical group help enhance positive beliefs about depression, quality of life, rumination response style, and divorced women`s metacognitions in an influential way. Shakeri, Parhun, Mohammad Khani, Hasani, and Parhun (2015) in their article "The impact of meta-cognition therapy on depression symptoms and the quality of life of depressed patients" came up with the conclusion 
that meta-cognition therapy has a major influence on depression symptoms and the quality of life of depressed patients. Therefore, given what has been stated so far, the aim of current is to find the impact of meta-cognition learning on perfectionism and the quality of life of high school students.

\section{Methodology}

In this research, a quasi-experimental plus pre-test and post-test design was used with a control group. The experimental and control groups were selected by convinent sampling method. Pre-tests were carried out on experimental and control groups before and after the intervention, then a post-test intervention was performed. The difference between pre-test and post-test in each group was studied based on the meaningfulness. The population of this study was all students of high school in Larestan city in the academic year 2017-2018. The sample of this study was 30 people who were selected using convenience sampling method. They were divided into two groups: experimental (15) and control group (15).

Hill's Perfectionism Questionnaire: Hill et al (2004) Perfectionism Measurement Questionnaire was used in this study (as cited in Jamshidi et. al, 2004, 2009). This scale has 59 items and 8 sub-scales as follows. Items $4,12,20,28,36,44,51,56$ assess order and organization sub-scale, items 5, 13, 21, 29, 37, 45, 52 assess purposefulness, items $1,9,17,25,33,41$ assess struggle for being the best, items 3 , $11,19,27,35,43,50$ assess the subscale of criteria for others, items $2,10,18,26,34$, 4249,59 asses sub-scale for the need to be confirmed, items $6,14,22,30,38,46$, 53, 57 assess sub-scale focusing on mistakes, items $7,15,23,31,39,47,54,58$, assess subscale for the parental pressure and questions $8,16,24,32,40,48$, and 55 form the subscale of the rumination of thought. Items were based on a five point Likert scale as follows: 5) totally agree, 4) agree, 3) neither agree nor disagree, 2) disagree, 1) totally disagree. On this scale, compatibility aspect of perfectionism is made by combining the first four dimensions, incompatibility aspect of perfectionism is formed by combining the next four dimensions. Jamshidi et al. (2009) found that the validity of this construct was confirmed by a factor analysis and its Cronbach's alpha coefficient for subscales was estimated to be in the range of 61 .. - 91 . 
Quality of Life Questionnaire (SF-36): this questionnaire was made by Veer and Sherbon (1992) in order to investigate the quality of life and health and consists of 36 items which covers and assesses 8 themes ranging from physical function, social function, performing physical role, performing emotional role, mental health, liveliness, physical pain to general health.

Furthermore, the 36-SF also provides two overall measurements: the overall physical component score (PCS) which measures the physical dimension of health, and the overall score of the mental component (MCS) which evaluates psychosocial dimension of health. The subject's score in each of these territories varies from 0 to 100 , and higher scores represent a better quality of life. The credibility and reliability of this questionnaire has been confirmed in the Iranian population (Montazeri et al., 2005; Asghari and Faghihi, 2003), and the internal consistency coefficients of the 8 subscales are between 0.70 and 0.85 and their retest coefficients with a one week interval have been reported between 0.43 and 0.79 . This questionnaire can also distinguish healthy people from patients in terms of all indices (Asghari and Faghihi, 2003). Descriptive statistics such as mean, standard deviation and inferential statistics of single-variable and multi-variable were used to analyze the data.

\section{Results}

\section{Table 1.}

Mean and standard deviation for the research variable in pre-test and post-test

\begin{tabular}{|l|l|l|l|l|l|}
\hline Variable & \multicolumn{4}{|l|}{ Pre-tes } & Post-test \\
\cline { 2 - 6 } & Group & $\begin{array}{l}\text { Mean } \\
(\mathrm{x})\end{array}$ & $\begin{array}{l}\text { Standard } \\
\text { deviation } \\
(\mathrm{SD})\end{array}$ & Mean & $\begin{array}{l}\text { Standard } \\
\text { deviation }\end{array}$ \\
\hline \multirow{3}{*}{ Perfectionism } & experimental & 99.95 & 12 & 85.65 & 12.31 \\
\cline { 2 - 7 } & control & 84.80 & 11.86 & 85.40 & 12.84 \\
\hline Quality of life & experimental & 171.20 & 19.72 & 189.70 & 20.50 \\
\cline { 2 - 7 } & control & 186.50 & 14.60 & 187.15 & 12.93 \\
\hline
\end{tabular}

The null hypothesis is accepted for the equality of the variances of the two groups in the variables of the research. That is, the assumption of equality of scores variance was confirmed in both experimental and control groups. Moreover, the null hypothesis 
for the normal distribution of the scores of the two groups in the research variables is confirmed. Namely, the normality assumption of the distribution of scores was confirmed in the pre-test and in both the experimental and the control groups. The $F$ value of the interaction for the sameness of the slope of the regression line is meaningless for all the research variables. In other words, the homogeneity of the slope of the regression line is accepted. By controlling the significant levels of all tests pre-test, it is indicated that there is a significant difference $(P<0.0001$ and $F=14.40)$ between the experimental and control groups in terms of one of the dependent variables (perfectionism and quality of life). The degree effect or difference is equal to 0.80 ; that is to say, $80 \%$ of the individual differences in post-test scores of perfectionism and quality of life are related to the effect of meta-cognitive therapy (group membership).

\section{Table 2}

test results

\begin{tabular}{|c|c|c|c|c|c|c|c|c|}
\hline $\begin{array}{l}\text { Variabl } \\
\text { e }\end{array}$ & $\begin{array}{l}\text { source } \\
\text { of } \\
\text { change } \\
\text { s }\end{array}$ & $\begin{array}{l}\text { sum of } \\
\text { square } \\
\text { s }\end{array}$ & $\begin{array}{l}\text { Degree of } \\
\text { freedom } \\
\text { (df) }\end{array}$ & $\begin{array}{l}\text { Mean } \\
\text { of } \\
\text { squares }\end{array}$ & $\mathrm{F}$ & Sig & $\begin{array}{l}\text { square } \\
\mathrm{s}\end{array}$ & $\begin{array}{l}\text { Statistic } \\
\text { al } \\
\text { power }\end{array}$ \\
\hline \multirow[t]{3}{*}{$\begin{array}{l}\text { Perfect } \\
\text { ionism }\end{array}$} & Pre-test & $\begin{array}{l}01.887 \\
4\end{array}$ & 1 & $\begin{array}{l}01.887 \\
4\end{array}$ & 74.127 & $\begin{array}{l}0001 . \\
0\end{array}$ & 0.77 & 1.00 \\
\hline & Group & $\begin{array}{l}36.307 \\
0\end{array}$ & 1 & $\begin{array}{l}36.307 \\
0\end{array}$ & 20.44 & $\begin{array}{l}0001 . \\
0\end{array}$ & 54.0 & 00.1 \\
\hline & error & $\begin{array}{l}18.257 \\
0\end{array}$ & 27 & 46.69 & & & & \\
\hline \multirow[t]{3}{*}{$\begin{array}{l}\text { Quality } \\
\text { of Life }\end{array}$} & Pre-test & 76.460 & 1 & 76.460 & 98.111 & $\begin{array}{l}0001 . \\
0\end{array}$ & 0.75 & 1.00 \\
\hline & group & 32.126 & 1 & 32.126 & 70.30 & $\begin{array}{l}0001 . \\
0\end{array}$ & 45.0 & 1.00 \\
\hline & error & 23.152 & 27 & 11.4 & & & & \\
\hline
\end{tabular}

\section{Discussion}


The findings of this study are compatible with the results of studies done by Parhun et al. (2012), Neshat Dust et al. (2009) who have shown that psychological interventions improve the quality of life of students. Quality of life consists of indices such as: physical health, mental health, social health, and environmental health. There was a significant difference between experimental and control groups in terms of physical health. In other words, given the fact that depression is related to the perceptions, and negative thoughts about physical health, it can be stated that after the reduction of depression in the thepeutical group, positive thoughts and positive thinking grows among the people in a way that they can better appraise their health. As a result, their score increase in this index of quality of life too.

One of the other influential indices in physical health is liveliness and being energetic which has a reversed relation with sadness and hopelessness considering the fact that sadness, hopelessness, boredom, and less energy are amongst the symptoms of depression. The more the patient feels depressed the less she will be lively and energetic. In this study, the fewer the symptoms of severe depression in the experimental group, the more the signs of liveliness. In conclusion, they can better assess their physical health. As the main source of meta-cognitive therapy is overcoming mental rumination and positive. negative beliefs about them, as a result of the reduction of mental ruination and positive. negative beliefs about them, depression decreases and the symptoms of depression disappear; hence, they can better assess the quality of their life.

There was also a significant difference between experimental and control groups in terms of perfectionism in post-test. In fact, perfectionist people reduce their activities in order to increase their mental rumination and their relaxation. That is because, they wrongly believe that mental rumination is a valuable opportunity for their health. Therefore, patients who undergo meta-cognitive therapy, the depressed person will not have a lot of time to get huddled over their negative thoughts, memories, and mental rumination as a result of doing meta-cognitive therapeutical techniques and activities. Consequently, this causes the patient to focus more on other aspects of his.her life and broaden his.her social relations. The current study also had the following limitations and delimitations: low sample size, accessible sampling method, selection of sample from among the high school students, three months of follow-up, 
and not controlling intelligence variable. In the end, in order to enhance the external validity of the findings, interested researchers in this area are recommended to study meta-cognitive therapy in a group with a higher number of samples and continue with follow-up studies It is also suggested that the effectiveness of this treatment should be compared with other therapies, including drug therapy and cognitive-behavioral therapy.

\section{Conclusion}

Although it is not the time to conclude the effectiveness of various therapeutical methods in the form of cognitive therapy, it seems that with an emphasis on the mutual relation between mental rumination, depression, and meta-cognition, metacognitive therapy of perfectionism and enhancing the quality of life stand in a better position in comparison with other theoretical models and is effective in reducing the severity of perfectionism and increasing the quality of life of high school students.

\section{Acknowledgement}

All the participants are thanked for their participation in this study.

\section{References}

Aghamohammadiyan Shaarbaf, H., Zarezadeh Kheibari, Huruf Ghannad M., Hokmabadi, M. (2014). A Study of the relation between perfectionism and sterile women`s sexual function, Iranian Journal of Obsterics, Gynecology, and Infertility, 17 (97), 9-17.

Gorzelsky, G., Driscoll, D. L., Paszek, J., Jones, E., \& Hayes, C. (2016). Cultivating constructive metacognition: a new taxonomy for writing studies. Critical Transitions: Writing and the Question of Transfer, 215.

Mashayekh, M., Heydari, H., (2014). Predicting the tendency to be addicted based on tolerance criteria, enthusiasm, and emotional intelligence among male students at a high school in Arak Province. 1st International Conference on Psychology and Behavioral Sciences, Tehran, Mehr-Eshraq Institute of Conferences, Center of Tehran University Conferences, retrieved from http...www.civilica.com.PaperRAFCON01-RAFCON01 302.html 
Mosavi Moghaddam, S., Zahirikhah, N., Bavarsad Jani, A., (2016). Predicting the relation between spiritual intelligence and perfectionism with contrastive strategies among the students at Shush Payam Noor University. 26 (1). 56-60.

Neshatdost H.T., Nilfroshzadeh M.A., Dehghani F., Molavi H (2009). Effectiveness of cognitive behavior stress management therapy on patient's quality of life with alopecia in skin disease and leishmaniusis research current of Isfahan, Journal of Arak University of medical science. 12. 125-132 [Persian].

Parhoon H, Moradi A, Hatami M, parhoon K (2012). Comparison of the Brief Behavioral Activation Treatment and Meta-cognitive Therapy in the Reduction of the Symptoms and in the Improvement of the Quality of Life in the Major Depressed Patients, journal of research in psychological health. 6(4):36-52 [Persian].

Razavi Zadeh, Z., Share H., (2015). A Comparison of meta-cognitive therapy group and teaching living skills effect on depression, quality of life, rumination response style, and metacognitions of divorced women. Iranian Journal of Psychiatry and Clinical Psychology. 20 (2), 108-120.

Seraji, A., Nasrabadi, T., Amirkhani, A. (2015). A Comparison of the quality of life of female medicine students living in dormitory and those who do not live in dormitory at Islamic Azad University, Medicinal Branch of Tehran. Aligudarz Nursing Faculty Analytic Research Journal. 3 (3 \& 4). 67-76.

Shakeri M., Parhun H., Mohammad Khani, S., Hasani, J., Parhun, K., (2015). The Impact of meta-cognitive therapy on depression symptoms and the quality of life of depressed patients. Journal of North Khorasan University of Medical Sciences, 7 (2). 253-265.

Trauelsen, A. M., Gumley, A., Jansen, J. E., Pedersen, M. B., Nielsen, H. G. L., Trier, C. H., ... \& Simonsen, E. (2016). Metacognition in first-episode psychosis and its association with positive and negative symptom profiles. Psychiatry research, 238, 14-23.

Yavariyan, R., Ramadan Pour, M., Asra and Radmehr M., (2017). A Study of the relation between perfectionism and mental health at Urmiah Medicinal University. Journal of Nursing and Midwifery. 15 (7). 497-503. 